\title{
PENGARUH ORIENTASI KEWIRAUSAHAAN DAN ORIENTASI PASAR TERHADAP KINERJA PERUSAHAAN MELALUI KEUNGGULAN BERSAING DAN PERSEPSI KETIDAKPASTIAN LINGKUNGAN SEBAGAI PREDIKSI VARIABEL MODERASI (Survey pada UMKM Perdagangan di Kabupaten Kebumen)
}

Oleh:

Setyawati, Harini Abrilia

Email: harini.abrilia.setyawati@gmail.com

\begin{abstract}
This research is done on the UMKM retail in Kebumen Regency, by the title "The influence of entrepreneurship and market orientation to performance by competitive advantage as mediation and it is moderated by the perception of environment uncertainty"

The purpose of this research is testing the influence of entrepreneurship and market orientation to performance by competitive advantage as mediating and the perception of environment uncertainty as moderating variable. This research is quantitative approach using survey method. The number of respondents is 100 shop owners in Kebumen regency which is determined by using Slovin's formula. Analysis's device that used is "Partial Least Square"

From the result of this research and data analysis can be concluded that entrepreneurship orientation gives positive impact to market orientation, entrepreneurship orientation gives positive impact to competitive advantage, market orientation does not influence to competitive advantage, entrepreneurship orientation does not influence to performance, market orientation does not influence to performance, competitive advantage does not influence to performance, entrepreneurship and market orientation does not affects to relation performance and competitive advantage and perception of environment uncertainty which does not moderating the relation of competitive advantage and performance.
\end{abstract}

Keywords : entrepreneurship orientation, market orientation, competitive advantage, perception of environment uncertainty and performance 
Persaingan di berbagai sektor semakin ketat pada era globalisasi sekarang ini. Dan persaingan tersebut tidak dapat dihindari, tidak hanya pesaing dari dalam negeri namun banyak tumbuh investor asing yang memasuki pasar Indonesia. Untuk dapat terus mempertahankan eksistensinya, maka sebuah perusahaan harus ikut bersaing. Hanya satu hal yang dapat dilakukan oleh perusahaan jika ingin terus eksis tanpa bersaing yaitu dengan menciptakan samudera biru, istilah Kim (2010) dalam buku Blue Ocean Strategy, dimana perusahaan mencari pasar yang belum ada pesaingnya. Namun tidaklah mudah bagi perusahaan untuk menciptakan pasar baru tersebut, maka jalan yang harus diambil adalah dengan bersaing. Persaingan dapat tercipta melalui strategi. Strategi dalam hal ini tercermin dalam orientasi kewirausahaan, orientasi pasar serta lingkungan.

Strategi menurut Mintzberg dalam buku Safari Strategi (1998) dibagi menjadi sepuluh mahzab, diantaranya adalah mahzab kewirausahaan. Kepemimpinan merupakan faktor penting dalam mahzab ini. Strategi perusahaan dipengaruhi oleh jiwa kewirausahaan pemimpin.

Orientasi kewirausahaan cenderung memiliki implikasi positif terhadap kinerja perusahaan. Hasil penelitian terdahulu Wiklund dan Shepherd (2005) mengidentifikasi hubungan positif antara orientasi kewirausahaan dan kinerja bisnis, demikian juga Wiklund (1999). Akan tetapi penelitian Frank et al. (2010) orientasi kewirausahaan berpengaruh negatif terhadap kinerja bisnis. Demikian juga penelitian terdahulu menunjukan lemahnya hubungan antara orientasi kewirausahaan dengan kinerja perusahaan (Lumpkin dan Dess, 2001). Adanya gap tersebut membuat peneliti tertarik untuk meneliti kembali hubungan orientasi kewirausahaan dengan kinerja perusahaan. Agar perusahaan mendapatkan keuntungan atas penerapan strategi, harus melalui keunggulan bersaing (competitive advantage). Sehingga orientasi kewirausahaan dalam penelitian ini selain secara langsung terhadap kinerja juga diprediksi mempengaruhi kinerja melalui keunggulan bersaing.

Orientasi kewirausahaan diyakini memiliki hubungan langsung dengan orientasi pasar. Matsuno et al. (2002) menemukan bahwa orientasi kewirausahaan mendorong orientasi pasar, sehingga semakin besar tingkat orientasi kewirausahaan, semakin besar tingkat orientasi pasar. Menurut Miller (1983) orientasi kewirausahaan merupakan suatu orientasi untuk berusaha menjadi yang pertama dalam inovasi produk pasar, berani mengambil risiko dan melakukan tindakan proaktif untuk mengalahkan pesaing.

Menurut Kohli dan Jaworski
(1990: 1-18), orientasi pasar merupakan budaya perusahaan yang bisa membawa pada meningkatnya kinerja pemasaran. Naver dan Slater (1990: 34) mendefinisikan orientasi pasar sebagai budaya organisasi yang paling efektif dan efisien untuk menciptakan perilaku - perilaku yang dibutuhkan untuk menciptakan superior value bagi pembeli dan menghasilkan superior performance bagi perusahaan. Perusahaan yang telah menjadikan orientasi pasar sebagai budaya organisasi akan berdasar pada kebutuhan dasar eksternal, keinginan dan permintaan pasar sebagai dasar dalam penyusunan strategi bagi masing - masing unit bisnis dalam organisasi, dan menentukan keberhasilan 
perusahaan. Menurut Nerver dan Slater (1990) mengemukakan temuan bahwa orientasi pasar berpengaruh positif terhadap kinerja pemasaran, sedangkan Morgan et al.(2009) menyatakan bahwa orientasi pasar tidak memiliki hubungan dengan kinerja sedangkan

Hubungan orientasi pasar tidak secara langsung berhubungan dengan kinerja, namun melalui keunggulan bersaing. Zhou et al. (2009) meneliti hubungan orientasi pasar, keunggulan bersaing dan kinerja perusahaan, dengan dua dimensi pada masingmasing variabel. Pengukuran kinerja menggunakan kinerja finansial dan non-finansial. Hasil penelitian tersebut menunjukan bahwa kinerja pasar full mediasi terhadap hubungan antara keunggulan diferensiasi dan kinerja keuangan.

Elbanna dan Alhwarai (2012) meneliti tentang pengaruh ketidakpastian lingkungan pada kinerja organisasi dengan mengambil dua sampel. Hasil dari penelitian tersebut adalah ketidakpastian produk merupakan satu-satunya dimensi dari ketidakpastian lingkungan yang berhubungan negatif dengan kinerja, dan ada pengaruh positif faktor ketidakpastian kebijakan pemerintah terhadap kinerja organisasi di Mesir. Dimensi ketidakpastian lingkungan lainnya yaitu ketidakpastian persaingan dan ketidakpastian ekonomi tidak berpengaruh terhadap kinerja organisasi. Berbeda hasil dengan penelitian yang dilakukan Miller (1993) dan juga Lonial dan Raju (2001). Hubungan keunggulan bersaing dengan kinerja diprediksi dapat meningkat melalui persepsi ketidakpastian lingkungan tersebut.

Penelitian ini bertitik tolak dari adanya masalah kontradiksi hasil penelitian Wiklund dan Shepherd (2005) berbeda hasil dengan penelitian
Frank et al. (2010) mengenai orientasi kewirausahaan dan kinerja, Elbanna dan Alhwarai (2012) ketidakpastian lingkungan dan kinerja, Morgan et al (2009) dan Zhou (2009) mengenai orientasi pasar dan kinerja. Studi ini berbeda dari penelitian sebelumnya dengan masing-masing penelitian terdahulu hanya menguji satu variabel bebas terhadap variabel terikatnya.

Penelitian ini melengkapi penelitian sebelumnya, yaitu menggabungkan beberapa variabel dan menambahkan variabel intervening berupa keunggulan bersaing pada hubungan orientasi kewirausahaan, orientasi pasar terhadap kinerja perusahaan. Keunggulan bersaing diambil, sebab melalui keunggulan bersaing diharapkan akan meraih kinerja yang unggul pula. Hubungan antara keungulan bersaing dan kinerja dapat dipengaruhi oleh faktor eksternal, maka penelitian ini menambahkan variabel moderasi ketidakpastian lingkungan pada hubungan keunggulan bersaing dan kinerja.

Sehingga dapat dirumuskan pertanyaan penelitian sebagai berikut;

1. Apakah orientasi kewirausahaan berpengaruh terhadap orientasi pasar?

2. Apakah orientasi kewirausahaan berpengaruh terhadap keunggulan bersaing?

3. Apakah orientasi pasar berpengaruh terhadap keunggulan bersaing?

4. Apakah orientasi kewirausahaan berpengaruh terhadap kinerja perusahaan?

5. Apakah orientasi pasar berpengaruh terhadap kinerja perusahaan?

6. Apakah keunggulan bersaing berpengaruh terhadap kinerja perusahaan 
7. Apakah keunggulan bersaing memediasi hubungan orientasi kewirausahaan dan kinerja perusahaan?

8. Apakah keunggulan bersaing memediasi hubungan orientasi pasar dan kinerja perusahaan?

9. Apakah persepsi ketidakpastian lingkungan memoderasi hubungan keunggulan bersaing dan kinerja perusahaan.

\section{METODE ANALISIS}

\section{Populasi dan Teknik Pengambilan} Sampel

Populasi pada penelitian ini sebanyak 277 usaha. Ukuran jumlah sampel ditentukan dengan menggunakan rumus Slovin (Husein, 2002) sebagai berikut :

$$
\begin{array}{cl} 
& n=\frac{N}{1+N \cdot \mathrm{e}^{2}} \\
\mathrm{n} \quad= & \text { Ukuran sampel } \\
\mathrm{N} \quad= & \text { Ukuran Populasi } \\
\mathrm{e} \quad= & \text { Presentase kelonggaran } \\
n=\frac{2 / l}{1+2 / 7 \cdot(0,1)^{2}} \\
\mathrm{n}=74
\end{array}
$$

Jumlah sampel minimal sebanyak 74 responden namun dalam penelitian ini jumlah sampel digenapkan menjadi 100 responden.

\section{Definisi Operasional Variabel}

Covin dan Slevin (1989) menekankan orientasi kewirausahaan pada metode maupun pengambilan keputusan meliputi inovasi, proaktif dan keberanian dalam pengambilan risiko.

Persepsi ketidakpastian Lingkungan menurut Miller (1993) merupakan persepsi individu untuk memprediksi lingkungan perusahaan (internal maupun eksternal) secara akurat dan berguna dalam pengambilan keputusan. Indikatornya adalah kebijakan pemerintah, faktor makro ekonomi, bahan/infrastruktur, produk, pasar dan permintaan serta kompetisi.

Kohli et al. (1993) orientasi pasar sebagai pencarian informasi tentang pasar berkaitan dengan keinginan konsumen untuk saat ini dan mendatang, penyebaran informasi ke seluruh organisasi, dan respon seluruh organisasi terhadap informasi tersebut.

Porter (1993) keunggulan bersaing adalah kemampuan suatu perusahaan untuk meraih keuntungan ekonomis di atas laba yang mampu diraih oleh pesaing di pasar dalam industri yang sama. Meliputi diferensiasi dan harga.

Kinerja menurut Morgan et al (2003) merupakan proses dan hasil kerja atas kemampuan untuk mengelola sumber daya. Kinerja dapat diukur melalui kinerja obyektif dan subyektif melalui persepsi.

\section{Teknik Analisis Data}

Teknik analisis data yang digunakan untuk menguji hipotesishipotesis dalam penelitian ini digunakan partial least square (PLS).

Outer model (outer relation atau measurement model) digunakan untuk menguji bagaimana setiap blok indikator berhubungan dengan variabel latennya (Ghozali, 2008). Hal ini dapat dilihat dari :

Convergent Validity digunakan sebagai ukuran validitas indikator dalam mengukur variabel latennya. Discriminant validity merupakan ukuran validitas konstruk dalam memprediksi ukuran indikator masingmasing bloknya. Composite reliability merupakan ukuran reliabilitas dari blok indikator dalam mengukur konstruknya (internal consistence). Besarnya 
composite reliability harus lebih besar dari 0,6 (Chin, 1998 dalam Ghozali, 2008).

Inner model yang kadang disebut juga dengan (inner relation, structural model, dan subtantive theory) menggambarkan hubungan antar variabel laten berdasarkan pada subtantive theory. Model struktural dievaluasi dengan menggunakan Rsquare untuk konstruk dependen. Interpretasinya sama dengan interpretasi pada regresi (Ghozali, 2008). Perubahan nilai R-square dapat digunakan untuk menilai pengaruh Pengujian hipotesis dapat dilakukan dengan memperhatikan tingkat signifikansi dan koefisien beta. Tingkat signifikansi digunakan untuk melihat signifikan tidaknya hubungan variabel laten independen terhadap variabel laten dependen.

\section{HASIL ANALISIS}

Outer model digunakan untuk menguji bagaimana setiap indikator atau items berhubungan dengan variabel latennya. Uji model pengukuran tersebut adalah:

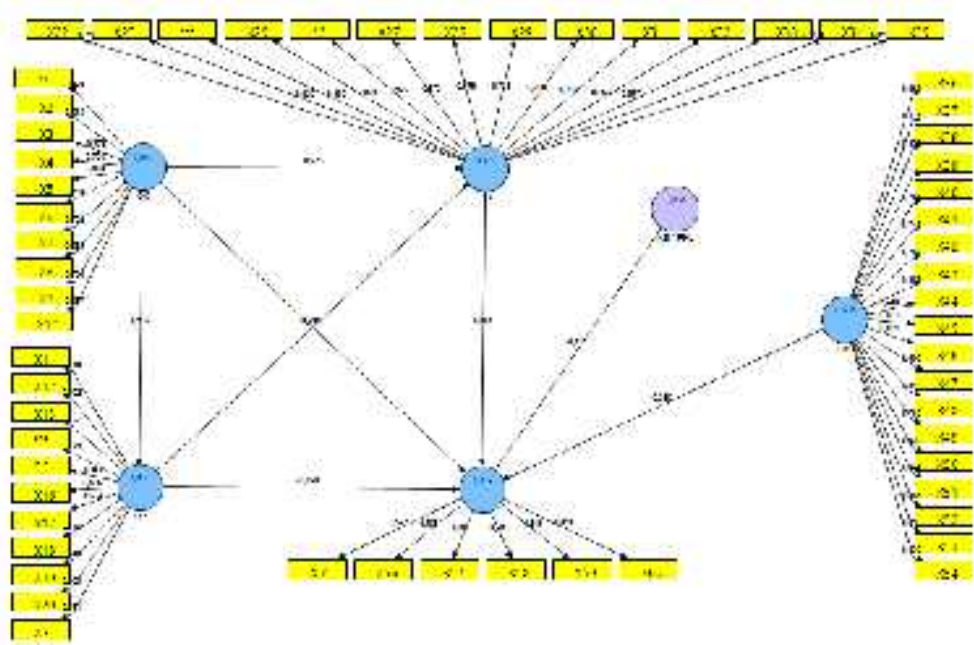




\section{Convergent Validity}

Butir pertanyaan (items) dinyatakan valid dan dapat digunakan untuk perhitungan dalam menganalisis hasil apabila skor komponen lebih besar dari nilai kriteria minimum yaitu 0,500 (Ghozali, 2008). Gambar 1 merupakan hasil perhitungan convergent validity.

Terlihat pada gambar 1 hasil perhitungan menunjukan X14 dan X15, X24 dan X26, X37, X38, X43, X44, X50 dan X51, skor berada di bawah 0,5 sehingga harus didelete, kemudian dire-estimate. Setelah di re-estimate terlihat pada gambar 2 skor sudah di atas 0,5 semua sehingga perhitungan dapat dilanjutkan pada proses berikutnya

\section{Gambar 1. Convergent Validity}

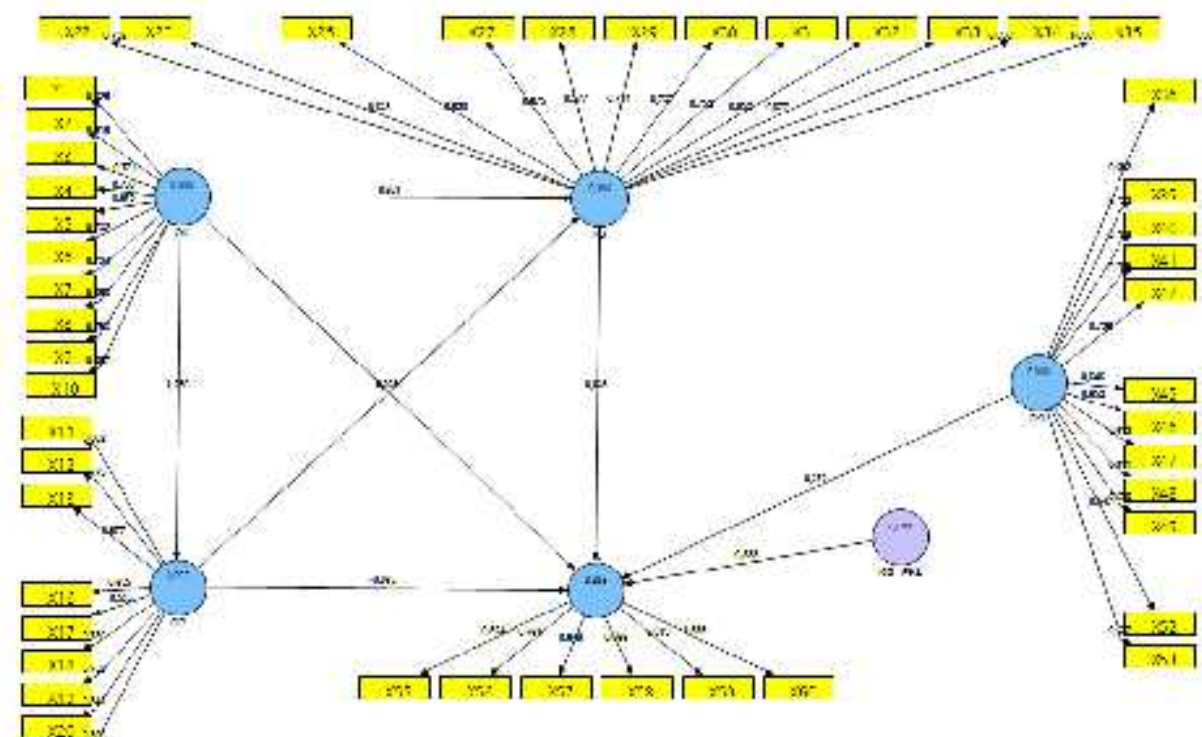

Gambar 2. Convergent Validity Re-estimate

Nilai AVE direkomendasikan harus lebih besar dari 0,5 (Chin, dalam Ghozali, 2008). Dilihat dari tabel berikut ini, terlihat bahwa AVE seluruh konstruk lebih tinggi dari 0,5 .

Tabel 1.

AVE

\begin{tabular}{lrrll}
\hline \multicolumn{1}{c}{ Variabel } & AVE & $\begin{array}{c}\text { Akar Kuadrat } \\
\text { AVE }\end{array}$ & \\
\hline Kinerja & & 0,612934 & 0,782901 & Diterima \\
Keunggulan Bersaing & 0,563357 & 0,750571 & Diterima \\
Orientasi Kewirausahaan & 0,616183 & 0,784973 & Diterima \\
Orientasi Pasar & 0,547888 & 0,740195 & Diterima \\
Persepsi Ketidakpastian Lingkungan & 0,508052 & 0,712778 & Diterima \\
\hline
\end{tabular}

diterima $>0,50$

Sumber: Data Diolah, 2013 
Selain nilai AVE yaitu nilai square root of average variance exracted (akar kuadrat AVE) dibandingkan untuk setiap konstruk dengan konstruk lainnya dalam model. Jika nilai akar kuadrat AVE setiap konstruk lebih besar daripada nilai korelasi antara konstruk satu dengan konstruk lainnya dalam model, maka dikatakan memiliki nilai discriminant validity yang baik (Fornell dan Larcker, 1981 dalam Ghozali, 2008).

Tabel 2.

Latent Variable Correlations

\begin{tabular}{cccccc}
\hline & K & KB & OK & OP & PKL \\
\hline K & 1 & & & & \\
KB & 0,081685 & 1 & & & \\
OK & 0,113948 & 0,3487 & 1 & & \\
OP & $-0,03498$ & 0,334959 & 0,255504 & 1 & \\
& & & & - & \\
PKL & 0,456334 & 0,148285 & 0,145449 & 0,06218 & 1 \\
\hline
\end{tabular}

Sumber: Data Diolah, 2013

Reliabilitas instrumen ditentukan dari nilai composite reliability. Composite reliability merupakan ukuran reliabilitas dari blok indikator dalam mengukur konstruknya (internal consistence).

Besarnya composite reliability harus lebih besar dari 0,60 (Chin, dalam Ghozali, 2008). Hasil output dari composite reliability konstruk di atas 0,60, sehingga dapat dilanjutkan tahap berikutnya.

Tabel 3.

Composite Reliability

\begin{tabular}{lcc}
\hline & Composite Reliability & Keterangan \\
\hline Kinerja & 0,901785 & Diterima \\
Keunggulan Bersaing & 0,938277 & Diterima \\
Orientasi Kewirausahaan & 0,941054 & Diterima \\
Orientasi Pasar & 0,915132 & Diterima \\
Persepsi Ketidakpastian Lingkungan & 0,924505 & Diterima \\
\hline \multicolumn{1}{c}{ diterima > $>, 60$} & &
\end{tabular}

Sumber: Data Diolah, Lampiran

\section{Pengujian Model Struktural (Inner Model)}

Model struktural dievaluasi dengan menggunakan $\mathrm{R}$-square untuk konstruk dependen. Interpretasinya sama dengan interpretasi pada regresi (Ghozali, 2008). Perubahan nilai R-square dapat digunakan untuk menilai pengaruh variabel laten independen terhadap variabel laten dependen 
Tabel 4.

R Square

\begin{tabular}{lc}
\hline & R Square \\
\hline \hline Kinerja & 0,353469 \\
Keunggulan Bersaing & 0,186263 \\
Orientasi Kewirausahaan & \\
Orientasi Pasar & 0,065282 \\
Persepsi Ketidakpastian Lingkungan & \\
\hline \multicolumn{2}{c}{ Sumber: Data Diolah, 2013 }
\end{tabular}

Sumber: Data Diolah, 2013

Tabel diatas menunjukkan bahwa :

a. Variabel kinerja dijelaskan oleh keunggulan bersaing, orientasi kewirausahaan, orientasi pasar dan persepsi ketidakpastian lingkungan sebesar $35,35 \%$

b. Variabel keunggulan bersaing dijelaskan oleh orientasi kewirausahaan dan orientasi pasar sebesar $18,63 \%$

c. Variabel Orientasi Pasar dijelaskan oleh Orientasi Kewirausahaan sebesar $6,5 \%$

\section{Pengujian Hipotesis}

Pengujian hipotesis dapat dilakukan dengan memperhatikan tingkat signifikansi dan koefisien path antar variabel laten. Untuk menguji hipotesis yang diajukan, dilakukan analisis statistik dengan memasukkan variabel yang diuji secara bersama-sama. Pengambilan keputusan didasarkan pada arah hubungan dan signifikansi dari model yang bersangkutan. Berikut adalah hasil output perhitungan Partial Least Square menggunakan software SmartPLS 2.0.

Tabel 5.

Path Coefficients (Mean, STDEV, T-Values)

\begin{tabular}{cccccc}
\hline & $\begin{array}{c}\text { Original } \\
\text { Sample } \\
(\text { O })\end{array}$ & $\begin{array}{c}\text { Standard } \\
\text { Error } \\
(\text { STERR })\end{array}$ & $\begin{array}{c}\text { T Statistics } \\
(\mid \text { OSTERR } \mid)\end{array}$ & T tabel & Keterangan \\
\hline \hline OK -> OP & 0,255504 & 0,097056 & 2,632539 & 1.66105 & Diterima \\
OK -> KB & 0,281493 & 0,077306 & 3,64129 & 1.66105 & Diterima \\
OP -> KB & 0,263037 & 0,093802 & 2,804169 & 1.66105 & Diterima \\
OK -> K & 0,021319 & 0,08006 & 0,26629 & 1.66105 & Ditolak \\
OP -> K & $-0,06461$ & 0,076957 & 0,839523 & 1.66105 & Ditolak \\
KB -> K & 0,03529 & 0,089624 & 0,393753 & 1.66105 & Ditolak \\
KB $*$ PKL -> K & $-0,38805$ & 0,344485 & 1,126474 & 1.66105 & Ditolak \\
PKL -> K & 0,371772 & 0,073053 & 5,089107 & 1.66105 & Diterima \\
\hline
\end{tabular}

Sumber: Data Diolah, 2013 
Berdasarkan tabel diatas, nilai original sample menunjukkan hubungan yang positif atau negatif antar variabel. Sedangkan $\mathrm{T}$ statistik digunakan untuk melihat signifikansi hubungan antar variabel. Hubungan dianggap signifikan jika $\mathrm{T}$ statistik lebih besar dibanding dengan $\mathrm{T}$ tabel. Dengan menggunakan tingkat keyakinan sebesar 95\% $(\alpha=0,05)$ dan degree of freedom $(d f)=(\mathrm{n}-\mathrm{k}-1)$ diperoleh nilai $\mathrm{T}_{\text {tabel }}$ sebesar 1.66105

Dengan demikian dapat disimpulkan bahwa :

H1 yang menyatakan bahwa Orientasi Kewirausahaan berpengaruh positif terhadap Orientasi Pasar diterima. $\mathrm{H} 2$ yang menyatakan bahwa Orientasi Kewirausahaan berpengaruh positif terhadap Keunggulan Bersaing diterima. $\mathrm{H} 3$ yang menyatakan bahwa Orientasi Pasar berpengaruh positif terhadap Keunggulan Bersaing diterima. $\mathrm{H} 4$ yang menyatakan bahwa Orientasi Kewirausahaan berpengaruh positif terhadap Kinerja ditolak. H5 yang menyatakan bahwa Orientasi Pasar berpengaruh positif terhadap Kinerja ditolak. H6 yang menyatakan bahwa Keunggulan Bersaing berpengaruh positif terhadap Kinerja ditolak.

Berdasarkan hasil uji Sobel (yang dihitung dengan menggunakan kalkulator Sobel, diperoleh nilai $\mathrm{t}$ hitung sebesar 0,391. Hal ini berarti nilai $t$ tabel one-tail probability sebesar 0,348 . lebih kecil daripada nilai $\mathrm{t}$ hitung sebesar 0,391 Sehingga hipotesis ketujuh yang menyatakan bahwa keunggulan bersaing memediasi hubungan orientasi kewirausahaan dengan kinerja, diterima.

Berdasarkan hasil uji Sobel diperoleh nilai $\mathrm{t}$ hitung sebesar 0,389. Nilai t tabel one-tail probability sebesar 0,189 . Dengan demikian dapat disimpulkan bahwa nilai $\mathrm{t}$ hitung lebih besar daripada nilai $\mathrm{t}$ tabel sehingga hipotesis kedelapan yang menyatakan bahwa keunggulan bersaing memediasi hubungan orientasi pasar dengan kinerja, diterima.

Berdasarkan tabel 5., menunjukkan bahwa nilai $\mathrm{T}$ statistik sebesar $1,126474<1.66105$ ( $\left.\mathrm{T}_{\text {tabel }}\right)$, hal ini berarti Persepsi Ketidakpastian Lingkungan tidak memoderasi hubungan Keunggulan Bersaing dan Kinerja. Hal ini berarti H9 yang menyatakan bahwa Persepsi Ketidakpastian Lingkungan memoderasi hubungan Keunggulan Bersaing dan Kinerja ditolak.

\section{KESIMPULAN}

Berdasarkan hasil hipotesis di atas diketahui bahwa hubungan antara orientasi kewirausahaan terhadap orientasi pasar adalah positif (berbanding lurus). Hal ini berarti bahwa penelitian ini mendukung penelitian Matsuno et.al (2002) yang menemukan bahwa orientasi kewirausahaan mendorong orientasi pasar, sehingga semakin besar tingkat orientasi kewirausahaan, semakin besar tingkat orientasi pasar. Pada UMKM ritel di Kabupaten Kebumen dapat dijelaskan bahwa, karakteristik jiwa kewirausahaan yang dimiliki oleh pemilik cukup baik. Dan kemampuan untuk inovasi, proaktif dan keberanian dalam mengambil risiko terbukti mempengaruhi strategi mereka dalam menghadapi pesaing, dan juga mengutamakan pelanggan. Inovasi yang dilakukan misalnya merubah layout toko menjadi seperti toko modern, misalnya pelanggan dapat memilih dan mengambil sendiri jenis barang yang diinginkan. 
Hubungan antara orientasi kewirausahaan terhadap keunggulan bersaing adalah positif (berbanding lurus). Sehingga penelitian ini mendukung penelitian Mahmood dan Hanafi (2013) yang menemukan bahwa orientasi kewirausahaan berhubungan dengan keunggulan bersaing. Pemilik toko ritel di Kabupaten Kebumen memiliki inovasi, proaktif dan pengambilan risiko yang tinggi. Inovasi yang diwujudkan melalui pelayanan, dan keberanian mengambil keputusan untuk merubah toko lama menjadi lebih modern membuat toko tersebut memiliki daya saing yang tinggi terhadap toko-toko lainnya.

Hubungan antara Orientasi

Pasar terhadap Keunggulan Bersaing adalah positif signifikan. Sehingga penelitian ini mendukung penelitian Zhou, Brown dan Dev (2009) yang menjelaskan hubungan orientasi pasar, keunggulan bersaing dan kinerja. Hal ini berarti bahwa strategi yang berorientasi pasar tersebut dapat meningkatkan daya saing toko terhadap toko lainnya. Keunggulan bersaing yang dimiliki adalah diferensiasi, bahwa toko mereka berbeda dari toko yang lain, terutama dalam hal pelayanan.

Hubungan antara Orientasi Kewirausahaan terhadap Kinerja adalah tidak signifikan. Berbeda dengan penelitian Wiklund dan Shepherd (2005), Awang, Liu et.al (2009), Hassim et.al (2011), Bhaumik et.al (2012) Mahmood dan Hanafi (2013), yang menyebutkan bahwa ada hubungan positif antara Orientasi Kewirausahaan dan Kinerja Bisnis. Bahwa semakin tinggi orientasi kewirausahaan maka kinerja perusahaan juga akan semakin tinggi. Orientasi kewirausahaan merupakan antecedent dari orientasi pasar, sehingga hal ini yang mempengaruhi hasil hubungan tersebut menjadi tidak signifikan. Penelitian yang akan datang dapat menjadikan orientasi pasar sebagai intervening dari hubungan keunggulan bersaing dan kinerja.

Hubungan antara Orientasi Pasar terhadap Kinerja adalah tidak signifikan. Penelitian ini berbeda dengan banyak penelitian lain yang telah meneliti hubungan orientasi pasar dan kinerja seperti penelitian Jaworski dan Kohli (1990), Narver dan Slater (1990), Pulendran et.al (2003) Zhou, Brown dan Dev (2009), Morgan et.al (2009) hingga Mahmoud (2011). Penelitian terdahulu menunjukan bahwa orientasi pasar berpengaruh positif terhadap kinerja perusahaan. Hasil dalam penelitian ini menunjukan bahwa orientasi pasar tidak berpengaruh terhadap kinerja, dalam penelitian Han et.al (1998) diketahui bahwa orientasi pasar berpengaruh terhadap kinerja dengan terlebih dahulu melalui inovasi. Sedangkan menurut Castanias dan Helfat (2001) penerapan strategi perusahaan tidak akan secara langsung mempengaruhi kinerja perusahaan. Agar perusahaan mendapatkan keuntungan atas penerapan strategi, harus melalui keunggulan bersaing (competitive advantage).

Hubungan antara Keunggulan Bersaing terhadap Kinerja adalah tidak signifikan. Sehingga penelitian ini berbeda dengan penelitian Ismail et al. (2010) yang menemukan hubungan keunggulan bersaing terhadap kinerja perusahaan. Berbeda dengan desain awal yang menggunakan pengukuran kinerja subyektif dan obyektif. Hasil penelitian ini hanya menggunakan pengukuran kinerja secara subyektif, sehingga akan lebih baik lagi jika penelitian yang akan datang menggunakan ukuran kinerja obyektif. Sebab jika menggunakan kinerja 
subyektif, persepsi responden dapat terlalu tinggi maupun terlalu rendah dari pengukuran kinerja sesungguhnya. Seperti dalam penelitian ini responden terlalu rendah dalam menilai kinerja mereka.

Variabel keunggulan bersaing memiliki pengaruh intervening (perantara) dari hubungan antara orientasi kewirausahaan dengan kinerja. Penelitian Mahmood dan Hanafi (2013) yang menguji efek mediasi keunggulan bersaing pada hubungan Orientasi Kewirausahaan terhadap Kinerja Perusahaan dan menunjukan hasil bahwa Keunggulan bersaing memediasi secara parsial terhadap hubungan orientasi kewirausahaan terhadap kinerja perusahaan. Sesuai dengan Castanias dan Helfat (2001) bahwa strategi tidak dapat langsung mempengaruhi namun terlebih dahulu dengan pencipataan keunggulan bersaing. Toko ritel yang ada di kabupaten Kebumen sudah bagus dalam orientasi kewirausahaan, dan hal ini berpengaruh terhadap keunggulan bersaing dan kemudian mempengaruhi kinerja toko tersebut.
Variabel keunggulan bersaing juga memiliki pengaruh intervening (perantara) dari hubungan antara orientasi pasar dengan kinerja. Zhou et al. (2009) meneliti hubungan orientasi pasar, keunggulan bersaing dan kinerja perusahaan, dengan dua dimensi pada masing-masing variabel. Hasil penelitian tersebut menunjukan bahwa kinerja pasar full mediasi terhadap hubungan antara keunggulan diferensiasi dan kinerja keuangan. Sama dengan hal nya orientasi kewirausahaan, orientasi pasar juga merupakan strategi yang tidak secara langsung mempengaruhi kinerja, namun melalui keunggulan bersaing. Variabel Persepsi

Ketidakpastian Lingkungan tidak memoderasi hubungan Keunggulan Bersaing dan Kinerja. Pengaruh moderasi disebabkan oleh variabel lain, dalam penelitian ini bukan oleh persepsi ketidakpastian lingkungan. Sehingga persepsi ketidakpastian lingkungan tidak mampu mempengaruhi hubungan keunggulan bersaing dan kinerja.

\section{DAFTAR PUSTAKA}

Awang, Amran et.al. 2009. Entrepreneurial Orientation and Performance Relations of Malaysian Bumiputera SMEs: The Impact of Some Perceivede Evironmental Factors. International Journal of Business and Management.Vol.4 ,No.9 : 84 - 96.

Beal,Reginald M. 2000. Competing Effectively, Environment Scanning, Competitive Strategy and Organizational Perfor,ance in Small Manufacturing Firms. Journal Of Small Business Management. January : 27-47.

Bharadwaj, Sundar G, P.R.Varadarajan, \& Fahly, Jihn. 1993. Sustainable Competitive Advantage in Service Industries: A Conceptual Model and Research Propositions. Journal of Marketing. Vol.57,Oktober,p.83-99

Coyne, Kevin P.1997. Sustainable Competitive Advantage - What It Isn't . Journal of Strategy.

Cross, Lisa. 1999. Strategy Drives Marketing Success. Graphic Arts Monthly.71(2):96. 
Daneshvar, Poolad. 2010. Review of Information Technology Effect on Competitive Advantage - Strategic Perspective. International Journal of Engineering Science and Technology.Vol2(11): 6248-6256.

Duncan, Robert B. 1972. Characterisics of Organizational Environments and Perceived Environmental Uncertainty.Administrative Science Querterly.Vol 17. No.3 : 313-327.

Droge, Cornelia \& Shownee Vickrey. 1994. Source and Outcomes of Competitive Advantage: An Explanory Study in The Furniture Industry. DecisionSciences. p.669-689

Elbanna, Said and Mohamed Alhwarai. 2012. The Influence of Environmental Uncertainty and Hostility on Organization Performance. Business Administration. hal $1-23$.

Faisal dan Tri Jatmiko Wahyu Prabowo. 2006. Pengaruh Intensitas Persaingan Pasar, Strategi dan Ketidakpastian Lingkungan yang Dirasakan terhadap Penggunaan Informasi Sistem Akutansi Manajemen dan Kinerja Unit Bisnis. JAAI .Volume 10 No.1: 45 - 63.

Ferdinand, Augusty. (2005). Structural Equation Modelling dalam Penelitian Manajemen". SeriPustaka Kunci No.06 Program Magister Manajemen Universitas Diponegoro

Frank, Hermann, Alexander Kessler and Matthias Fink. 2010. Entrepreneurial Orientation and Busiess Performance - A Replication Study. Entrepreneurial Orientation. SBR 62: 175 - 198.

Gatignon, Hubert\& Jean - Marc Xuerob. 1997. Strategic Orientation of The Firm and new Product Performance. Journal of Marketing Research. p.77-79

Getz, Gary A .dan Frederick D. Strudivant.1989. The Nuts and Bolts of Formulating Differentiation Strategy. Planning Review. 17(5) : 4-9 .

Hassim, Affendy Abu et.al. 2011. The Effects of Entrepreneurial Orientation on Firm Organisational Innovation and Market Orientation Towards Firms Business Performance. International on Sociality ND Economics Development. IPEDR Vol.10: 280 -284.

Kutcher, Kevin. 2001. Differentition. Rural Telecommunications. 19 (1) : 14.

Liao, Shu-Hsien, Ta-Chien Hu. 2007.Knowledge Transfer and Competitive Advantage on Environmental uncertainty : An Empirical Study of The Taiwan Semiconductor Industry.Technovation. Vol.27. Issues 6 -7 : 402 411.

Lumpkin, G. T. 1996. Clarifying The Entrepreneurial Orientation Construct and Linking It to Performance. Academy of Management Review. Vol.21 No.1 : $135-172$.

Mac Millan, Ian C. dan Rita Gunther McGrath.1997. Discovering New Points of Differentiation. Harvard Business Review : 133-138.

Mahmood, Rosli, Norshafizah Hanafi. 2013. Entrepreneurial Orientation and Business Performance of Women-Owned Small and Medium Entreprises in 
Malaysia : Competitive Advantage as a Mediator.International Journal of Business and Social Science. Vol.4 No. 1 : 82 -90.

Narver, J.C., \& Slater, S.F. 1990. The Effect of Market Orietation on Product Innovation. Journal of Marketing. p.20-35.

Porter, Michael, E. 1990. Competitive Strategy. The Free Press. New York,p.20

Satyagraha, Hadi. 1994. "Keunggulan Bersaing dan Aliansi Strategis: Resefinisi SWOT". Usahawan. No.4,Th.XXIII.

Swamidaa, Paul M. and William T. Newell. 1987. Manufacturing Strategy, Environmental Uncertainty And Performance : A Path Analytic Model. Management Science. Vol.33 : 509 -523.

Wahyono. 2002. "Orientasi Pasar dan Inovasi: Pengaruhnya Terhadap Kinerja Pemasaran". Jurnal Sains Pemasaran Indonesia. Vol.1,No.1,Mei.

Wang,Chaterine L. 2008. Entrepreneurial Orientation, Learning Orientation and Firm Performance.Entrepreneurship Theory and Practice. 32(4) : 635 656.

Weerawardena, Jay. 2003. Exploring The Role of Market Learning Capability in Competitive Strategy. European Journal of Marketing. Vol.37,p.407-429

West, Joel. 2010. The Effects of Environmental Uncertainty on Young and Small Business.Effect of Environmental Uncertainty. October $1: 1-25$.

Wibisono, D. 2006. Manajemen Kinerja: Konsep, desain, dan Teknik Meningkatkan DayaSaing Perusahaan. Bandung: Erlangga.

Wibowo. 2010. Manajemen Kinerja. Jakarta: Rajawali Pers

Zhou, Kevin Zheng, James R. Brown, Chekitan S. Dev. 2008. Market Orientation, Competitive Advantage, and Performance : A Demand-Based Perspective.Journal Of Business Research. 62 : $1063-1070$. 